\title{
Scale of Tax Frauds as A Threat to the State's Financial Security
}

\author{
MONIKA PASTERNAK-MALICKA \\ Department of Finance, Banking and Accounting \\ Rzeszow University of Technology \\ Al. Powstancow Warszawy 12, Rzeszow 35-959 \\ POLAND
}

\begin{abstract}
The objective of the paper is an attempt to assess the impact of the scale of tax frauds on the financial security of the state. In the paper one tried to assess the relationship between the level of informal economy and the fiscal income of the state, but also, based on the survey research, to indicate whether unethical attitudes of taxpayers meet with social consent and constitute an incentive to bypass the tax law. Methodology: Achieving the goal required the use of descriptive and statistical methods, in particular the linear regression method. The direct method - questionnaire was also applied. Results: In the paper the essence of the informal economy in the years 1994-2018, as well as the ethical determinants of tax evasion in the light of the author's own research from 2007-2020 were discussed. Based on statistical data, an attempt was made to assess the impact of the informal economy, understood as evasion of fiscal obligations, on tax revenues in Poland, based on the linear regression method. The scope of the phenomenon of tax pathology as the basic element of the shadow economy and its impact on the level of tax income seems to be confirmed by the relationship shown by the method of estimating the expected value - variable, which showed that the shadow economy, calculated according to F. Schneider's estimates, was a factor in $94 \%$ determining the level of tax revenues in the years 2000-2017.
\end{abstract}

Key-words: financial security, informal economy, tax frauds, state finance

Received: August 4, 2021. Revised: November 15, 2020. Accepted: December 26, 2021. Published: January 12, 2021

\section{Introduction}

Tax, in its construction, forces taking over of a part of income or property. Therefore, it is often perceived as a benefit that limits consumption, investment and freedom of the individual. Tax deprived of the value of neutrality generates economic and social effects, and thus significantly determines the behavior of market participants. This behavior may be influenced by moral factors related to ethics and the condition of public awareness. The development of civilization, accelerated progress of science and technology led, on the one hand, to an improvement in the economic conditions of living in modern societies, and on the other one, a noticeable decline in the morality of citizens is also emphasized, which translates into a tendency to tax fraud.

The aim of the paper is an attempt to assess the impact of the scale of tax fraudsters on the financial security of the state. The informal economy, as a consequence of tax fraud, reduces $s$ the tax revenues of the state significantly, and at the same time weakens its financial security. In the paper the essence of the informal economy, as well as the ethical conditions of tax evasion in the light of the author's own research from 2007-2020 were discussed. Based on statistical data, an attempt was made to assess the impact of the informal economy, understood as evasion of fiscal obligations, on tax revenues in Poland, based on the linear regression method. The paper is an attempt to indicate the lack of ethical behavior, whose consequence is the tendency to tax fraud as a threat to the financial security of the state.

\section{The concept and scale of informal economy}

Informal economy, often referred to as the shadow economy, is an ambiguous concept, as the literature on the subject offers many, often similar, but also contradictory definitions. The diversity of definitions results from different goals of researchers of this phenomenon and the diversity of socio-economic systems subject to observation $[1,2]$. The most popular 
view is that this is an activity that is not subject to registration in the national accounts. It is often emphasized that this is an activity that amounts to tax evasion. Hence, the informal economy is called by many financiers "tax dexterity" or an abuse of tax law [3]. Such an approach is the focus of this paper

According to E.L. Feige shadow economy is part of economic activities whose income is exempt from legal regulations, taxation and observation of official bodies. All these activities have one thing in common - people involved in them try to hide their income from government bodies [4]. D. Cassel and A. Caspers understand the concept of unofficial economy as all forms of economic activity that are not regulated by law and are not subject to taxation [5]. Similarly, F. Schneider uses the term to describe market activity consisting in the production of non-banned products, hidden from public control, in order to avoid the payment of taxes, social benefits or other regulations [6]. S. Pozo, in turn, defines it as economic ventures that are carried out outside the legal norms [7]. L. Balcerowicz points out that the shadow economy includes tax-free income generated in the production of legal goods and services. It is associated with nonpayment of taxes, although the desire to avoid them does not have to be the only motive for the action [8]. A similar feature was noted by Z. Rajewski and L. Zienkowski who emphasize that the goal of entities operating in the informal sector is to consciously avoid paying cash benefits to the state [9]. Also K. Dzierżawski defines the phenomenon of the shadow economy as mainly consisting in tax evasion [10]. Indirectly, in the long term, this phenomenon may be, among other things, a key source of risk for business operations [1112]. In the National Accounts, the shadow economy includes production activities that are completely legal, but hidden from public authorities in order to avoid paying taxes and social security contributions [13].

Not only is the definition of the shadow economy imprecise. Similarly, the estimates of this phenomenon, due to its "elusive" nature, are difficult to measure. In the longest time horizon, the estimates of the size of the informal economy in Poland are made by the Central Statistical Office. Figure 1 shows the share of the shadow economy in generating GDP in 1994-2018. In 1994, this share was at the highest level of $17.2 \%$, after which it started declining systematically until 2000, when it increased again to $17 \%$. In 2008 , it fell to the lowest level, estimated at $11.8 \%$ of GDP. In the following years, along with the economic slowdown resulting from the subprime crisis, the index increased by 1-2 percent points. In 2012-2015, the share of the shadow economy in the Polish economy amounted to an average of $13.4 \%$. The lowest level was recorded in 2012 (13.0\%), and the highest in 2013 (13.8\%) [14]. In 2018, the share of the unobservable economy was estimated at $12.0 \%$ of GDP, of which the shadow economy in registered units was $10.0 \%, 1.7 \%$ due to undeclared work, and $0.3 \%$ of GDP [15].

Figure 1. The shadow economy in Poland according to the Central Statistical Office in 1994-2018 (in \%)

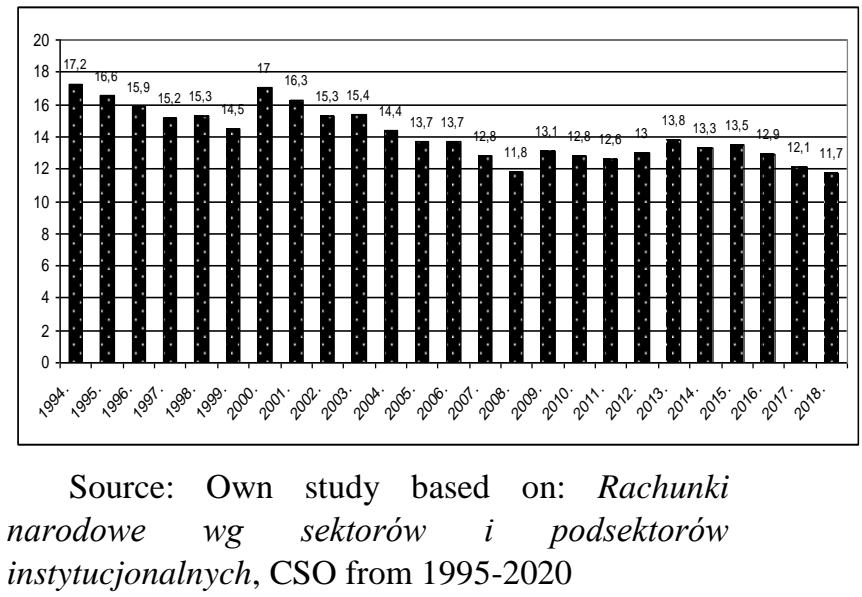

The shadow economy is calculated at a slightly higher level by the Institute of Economic Forecasts and Analyzes (IPAG), according to which the total value of the unobservable economy in 2019 amounted to PLN 242 billion, which accounted for $17.2 \%$ of GDP (in $2016-19.0 \%, 2017-18.7 \%$ of GDP, in $2018-18.0 \%$ ) [16]. On the other hand, the highest indications are visible in the achievements of Friedrich Schneider who specializes in research on the shadow economy 
based on the MIMIC (Multiple Indicators Multiple Causes) method. It calculates the share of the unofficial economy in GDP in Poland at the level of $22.2 \%$ of GDP in 2017 (22.7\% in $2016 ; 23.3 \%$ in 2015) [17] - Figure 2.

Figure 2. The shadow economy according to F. Schneider in Poland in 2000-2017 (in \% of GDP)

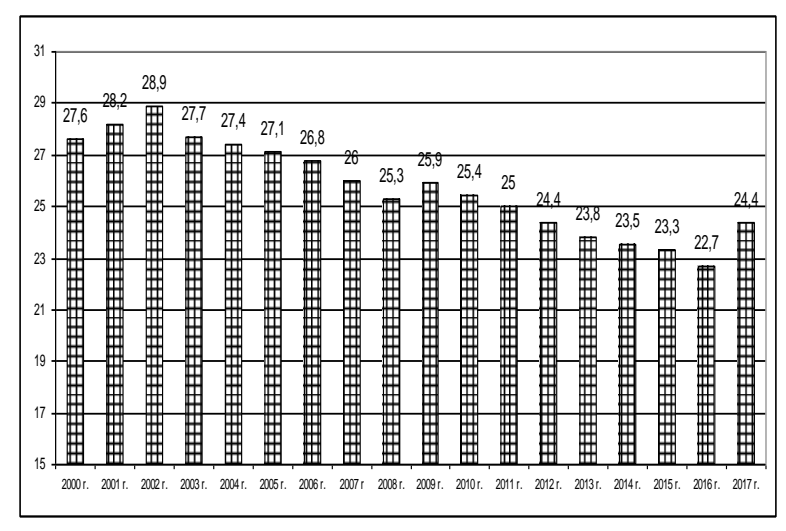

Source: Own study based on:[18-22]

From Schneider's estimates it can be concluded that about one-fifth of the conducted economic activity is unregistered in Poland. Its largest part is the so-called hidden activities, i.e. unregistered transactions and turnover of legally operating enterprises. What stands out in the activity in the shadow economy is the understatement of income for the purpose of lowering tax liabilities.

\section{The relationship between the shadow economy and tax revenues}

In the paper the linear regression method (the method of estimating the expected value of a variable) was applied to investigate whether there was a statistical relationship between the shadow economy determining the scale of fiscal fraud and the state's tax revenues. Figures 3.-4. present a dispersion chart, which is a graphic interpretation of the correlation between the level of the informal economy and the level of tax income in the years 2000-2018. Both charts show a negative correlation, which means that the increase in the shadow economy will be accompanied by a decrease in tax revenues.

Figure 3. Scattering diagram between the scope of the shadow economy according to Schneider and tax revenues in Poland in the years 2000-2017

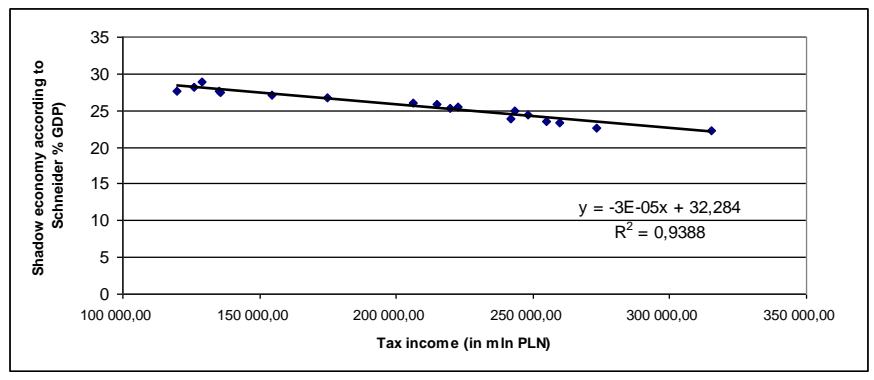

Source: Own calculations based on Figure 2 and reports on budget implementation for 2000-2020.

Figure 4. Scattering diagram between the scope of the shadow economy according to GUS and tax revenues in Poland in 2000-2018

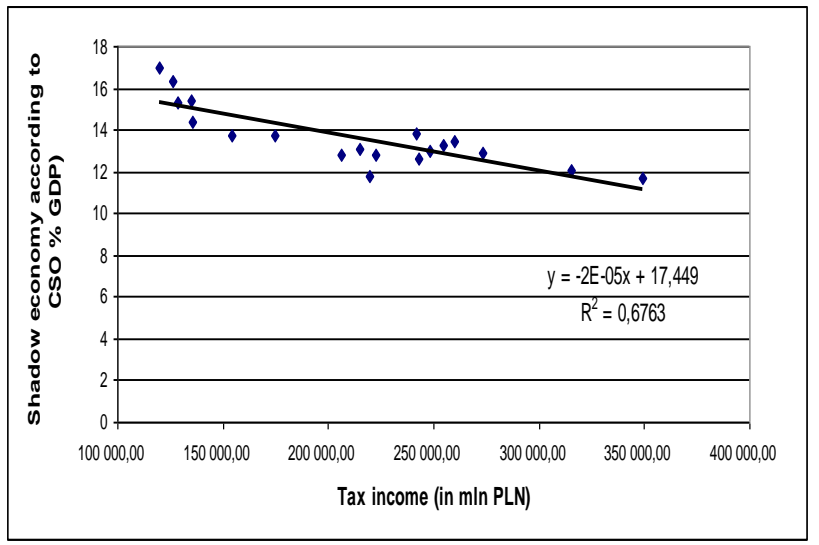

Source: Own calculations based on Figure 1 and reports on budget implementation for 2000-2020.

Figure 3 shows the relationship between the estimates of the shadow economy according to F. Schneider and the level of tax revenues in Poland in 2000-2017. Using the linear regression method, a trend line was defined. Its formula is located in the lower right corner of the chart. Below ther is the $\mathrm{R}^{2}$ coefficient, i.e. the determination indicator. Its value was 0.9388 , which meant a very strong 
(94\%) correlation between the scale of tax fraud and fiscal revenues.

Figure 4 was prepared for the estimates made by the Central Statistical Office. The value of the determination index in this case was 0.6763 and indicates a satisfactory statistical relationship. The fact that the intuitive dependence was not shown at an equally high level resulted from the adopted different research methodology.

\section{Methodology}

Achieving the goal required the use of descriptive and statistical methods, in particular the linear regression method. The direct method - questionnaire was also applied. The own research was conducted on a deliberate sample of 686 households and 219 business entities (in May 2007), 750 households and 250 business entities (in May 2009), 1084 households and 250 business entities (in April and May 2010), 1201 households and 281 business entities (in May 2011), 1230 households and 232 business entities (in January 2012), 1128 households and 237 business entities (in January 2013), 857 households and 188 business entities (in January 2014), 852 households and 244 business entities (in January 2015), 1103 households and 325 business entities (in January 2016), 1038 households and 289 business entities (in January 2017), 883 households and 225 business entities (in January 2018), 758 households and 265 business entities (in January 2019) and 975 households and 268 business entities (in January 2020). The interviews were conducted in the Podkarpackie Province. The surveys were addressed to entities from the SMEs sector with a diversified level of turnover, the number of employees and the period of functioning in the market, as well as people over 20 years of age with a diversified level of income and living standard.

Research from the years 2007-2020 was used to develop Figure 5, while in the remaining years, due to the extension of the scope of the research, new issues were added regarding the issues under study. The year 2008 was omitted for reasons beyond the control of the author of the paper. Due to the multi-faceted approach to the analyzed topic, an attempt was made to research both households (often participants of the shadow economy) and economic entities that may act as initiators of tax fraud, when their situation on the market is uncertain or due to increase the level of the achieved income.

\section{Ethical determinants of tax evasion and the scale of the phenomenon in the light of own research}

In the public awareness, a failure to pay the tax is not always assessed negatively, and effective escape from it may give a sense of satisfaction. Moreover, it is often believed that taxes are high and unfair, and tax law is unclear and inconsistent. Such circumstances reduce the sense of guilt in the event of tax evasion. At the same time, tax crimes may pose a threat to the financial security of the state, as both their scale and impact not only reduce tax revenues, but also force other economic entities that wish to cope with competition from companies that fail to meet fiscal obligations to enter the shadow economy.

Author's own research conducted in the years 2007 - 2020 confirmed that tax fraud was not negatively assessed by a significant part of the population. Figure 5 presents the structure of the answer to the question about the opinion on concealing income. In the years 2007-2011, almost $30 \%$ of people believed that such behavior should be condemned, in 2012 and 2014 the percentage of people expressly condemning such behavior fell to $26-25 \%$, and in 2015 only $23.4 \%$ of people chose this option. Every year, nearly half of the respondents justified tax fraud with high levies. Initially, there was also an increase in the percentage of people (from 3.6\% in 2007 to $6.6 \%$ in 2013 and $10.1 \%$ in 2016) who approved of concealment of income, and considered it as a manifestation of 
resourcefulness in life, but in recent years there has been a noticeable tendency decreasing. In 2020 , only $4.1 \%$ of people have assessed tax fraud as a sign of cleverness, but still every third respondent is looking for an explanation for tax evasion due to too high fiscal burdens.

Figure 5. Structure of answers to the question: What do you think of cases when people withhold part of their earnings in order to reduce taxes paid?

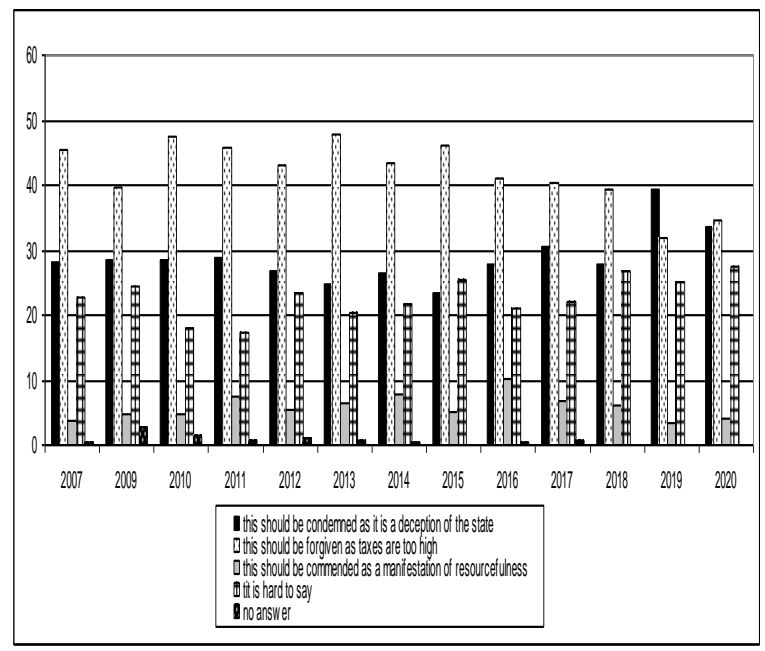

Source: Own calculations based on surveys conducted in 2007 - 2020.

Table 1. Structure of answers to the question: How do you evaluate the attempts to avoid paying taxes?

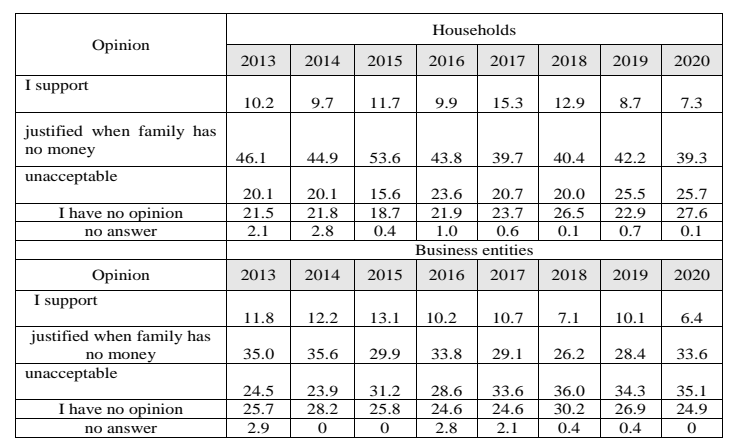

Source: Own calculations based on surveys conducted among households and business entities in 2013-2020

Ethical attitudes are influenced by the public perception of the state as an anonymous institution, which gives rise to the belief that no one will be harmed as a result of tax fraud. The assessment of the attempt to escape the tax was met with nearly $10 \%$ support among the surveyed households (Table 1), and almost half of the respondents justified it with a lack of livelihood, and only every fifth respondent found tax evasion unacceptable. In 2015, there was an increase in attitudes justifying tax fraud (53.6\% of the answers provided), while in 2020 a decrease - 39.3\%. Although entrepreneurs explain the possibility of committing tax crimes to a lesser extent with a very bad financial condition of the company (on average every third respondent), the level of support for unethical behavior in this group is slightly higher (in $2010-11.8 \%$, in 2015 $13,1 \%)$.

Table 2 presents opinions on the size of tax fraud in Poland. According to the vast majority, the scale of the phenomenon was either very large $(18.5 \%$ in $2007,21 \%$ in 2020 ) or large $(54.5 \%$ in $2007,57.8 \%$ in 2020).

Table 2. Structure of answers to the question: What, in your opinion, is the scale of losses in Poland resulting from hiding income while paying taxes?

\begin{tabular}{c|c|c|c|c|c|c|c|c|c|c|c|}
\hline \multirow{2}{*}{ Opinion } & \multicolumn{10}{|c|}{ Percentage structure } \\
\cline { 2 - 14 } & 2010 & 2011 & 2012 & 2013 & 2014 & 2015 & 2016 & 2017 & 2018 & 2019 & 2020 \\
\hline very high & 18.5 & 23.8 & 22.9 & 21.4 & 22.3 & 20.7 & 16.1 & 24.4 & 22.8 & 22.4 & 21.0 \\
\hline rather high & 54.5 & 54.4 & 55.9 & 53.9 & 57.2 & 59.2 & 55.2 & 53.1 & 57.9 & 57.9 & 57.8 \\
\hline rather low & 19.8 & 16.6 & 16.4 & 20.2 & 15.8 & 16.7 & 21.7 & 17.3 & 15.4 & 15.1 & 16.5 \\
\hline very low & 3.6 & 2.8 & 2.4 & 2.7 & 2.8 & 3.3 & 6.3 & 4.4 & 3.9 & 2.8 & 3.0 \\
\hline I don't know & 0 & 0.3 & 1.0 & 0.8 & 0.7 & 0.1 & 0 & 0 & 0 & 0 & 0.5 \\
\hline no answer & 3.5 & 2.2 & 1.3 & 1.0 & 1.3 & 0.1 & 0.6 & 0.8 & 0.1 & 1.8 & 1.1 \\
\hline
\end{tabular}

Source: Own calculations based on surveys conducted in $2010-2020$.

The impact of the unethical attitude of taxpayers on the state's financial security cannot be clearly defined. Nevertheless, there is no doubt that taxes constitute a significant state income, in the range of $85-90 \%$ of budget revenues, and the decline in tax morality and the lack of ethics in the attitudes of citizens are conducive to increasing the scale of tax fraud. This, in turn, translates into a reduction in tax revenues. 


\section{Conclusions and discussion}

Avoiding or reducing tax liabilities by means of legal instruments is a common phenomenon in modern countries, and at the same time illegal reduction of tax burdens accompanies economic processes and taxpayers' behavior in all modern countries. Taxpayers compare the benefits of not paying taxes with their risk. It is indicated that the risk of control is low, often does not reach the level of statistical significance, yet a relevant proportion of people regulate their tax liabilities, which results, among other things, from their moral obligation.

Tax fraud as a manifestation of unethical attitudes poses a real threat to the financial security of the country as it reduces the income of the state and local government. They also pose a threat to the economic operators themselves when they are identified. Due to their financial consequences, they may be exposed to bankruptcy [23,24]. It seems that official statistics do not reflect the whole and complexity of what can be described as tax disloyalty. It is not without reason that the President of the European Commission from 2004-2014 - Jose Manuel Barroso, recognized that tax fraud infringed the foundations of a modern democratic state.

In Poland, the phenomenon of crime against tax obligations operates at such a level of illegal absorption of funds that it may pose a threat to the stability of the state budget policy. It is estimated that the level of informal economy, depending on the adopted methodology, ranges from $11.7 \%$ of GDP according to CSO, $17.2 \%$ of GDP - according to Market Research Economy Institute, or according to F. Schneider's calculations - as much as $24.4 \%$ of GDP. The scale of this phenomenon, translated into nominal values, is, according to the estimates of the Austrian researcher, at the level of almost PLN 400 billion, and constitutes about one quarter of the Gross National Product.

The scope of the phenomenon of tax pathology as the basic element of the shadow economy and its impact on the level of tax income seems to be confirmed by the relationship shown by the method of estimating the expected value - variable, which showed that the shadow economy, calculated according to F. Schneider's estimates, was a factor in $94 \%$ determining the level of tax revenues in the years 2000-2017.

At the same time, the respondents' tendency to unethical behavior is high and is characterized by growing dynamics. There is also a noticeable lack of stigmatization by the society of immoral behavior and its growing acceptance by society.

One of the most significant negative aspects of tax crimes affecting the financial security of the state is the disruption of competitive mechanisms. Entities operating in the shadow tax zone are becoming more competitive in terms of prices than companies operating fully legally. The shadow economy means avoiding taxation (both direct and indirect taxes), which in turn enables dishonest entrepreneurs to offer their customers goods and services at lower prices. Often these are prices that are not able to be offered by entities honestly fulfilling the tax obligation, as this would adversely affect their profitability and even mean losses.

The price criterion becomes particularly important in periods of economic downturn, when consumer incomes do not grow so fast, which translates into a constraint on the demand side. Then entrepreneurs, especially small and medium-sized enterprises, so far loyally regulating the tax and insurance obligations of employees, in order not to lose price competition with entities from the shadow economy, quite quickly decide to circumvent tax obligations.

Distortion of market competition by entities perpetrating tax evasion leads to a situation when price is the most important factor of competition. As a result, entrepreneurs pay less and less attention to such elements of competitive struggle as quality or product innovation. The tendency to fraud may also depend on the legal form of the entity $[25,26]$. In the macroeconomic scale this results in a decline in expenditure on research and development, which translates into deterioration of the international competitiveness of the economy and indirectly adversely affects the slowdown in economic growth. This affects the creditworthiness of the state, its credibility on financial markets, and, consequently, the financial security of the state. International studies also note that the decline in tax revenues has an impact on the country's poverty level [27-28] 
The aforementioned macroeconomic aspect related to the depletion of the state's tax revenues by fiscal fraud has its further negative consequences in the form of limiting the possibilities of easing fiscal policy. In a situation where some taxpayers avoid paying the levy, other market participants are charged with higher taxes. Higher taxes, in turn, are a significant temptation and a reason to operate in the shadow economy. In this way, the circle is closed and the only way to break it is to take systemic actions aimed at limiting the scope of tax crimes, the scope of which is affected by ethical attitudes. Research on tax morality by B. Torgler has shown that lowering tax morality by one unit leads to an increase in the size of the shadow economy by $20 \%$ [29].

In countries where research into the problem of tax morality was conducted, the taxpayers' responses indicated that the assessment of tax fraud was neutral or quite mild in the public perception. Respondents believed that when calculating the tax, one should use borderline measures to minimize the tax burden.

The moral assessment of tax evasion does not always have to be unequivocal. In the Catechism of the Catholic Church tax evasion is considered morally wicked, but the circumstances in which the unlawful act takes place are important. These conditions contribute to the lack of a negative assessment among households and business entities participating in the survey. For nearly half of the representatives of households, the excuse for tax fraud is the lack of financial resources needed to support the family, and for every third entrepreneur the explanation was the poor condition of the company on the verge of bankruptcy.

It is disturbing that there is a growing belief that tax fraud is a manifestation of resourcefulness, and at least $40 \%$ of people are looking for an explanation, either in the amount of fiscal burden or lack of livelihood. As empirical studies show, the situation when there is a reduction in tax is a sufficient justification of tax evasion for many of the respondents. At the same time, it should be emphasized that apart from the ethical determinants of tax evasion, there are many reasons motivating fiscal fraud [30].

No tax system has ever been, and will not be based on trust in the taxpayer and his conscience, and resistance to the fulfillment of tax obligations will always be related to the reluctance to pay levies. At the same time, it should be remembered that by paying taxes, a citizen takes part in building the common good and uses the benefits and goods offered to him by the state. It seems that as long as fiscal fraud will cease to be perceived as an act of self-defense and entrepreneurial attitude, and unethical attitudes will be socially stigmatized, then the scale of tax fraud will decrease to a negligible extent. Some relevant studies can be found in [31], [32], [33].

\section{References}

[1] Mróz, B. (2001). Metody pomiaru gospodarki nieoficjalnej, „Ekonomista”, no. 1, 2001, p. 93.

[2] Zimon, G. (2020). Management Strategies of Working Capital in Polish Services Providing Companies, 2020. WSEAS Transactions on Business and Economics, Volume 17, 2020, pp. 225-230

[3] Martinez, J.C. (1984). La fraude fiscale, Paris 1984, p. 11. [Following:] M. Kalinowski, Granice legalności unikania opodatkowania $w$ polskim systemie podatkowym, TNOiK, Torun 2001, p. 24.

[4] Feige, E.L. (1989). The underground economy. Tax evasion and information distortion, Cambridge University Press, 1989, p. 2.

[5] Cassel, D., Caspers, A. (1984). Was ist Schattenwirtschaft? Begriff und Erscheinungsformen der Sekond Economy, Wisrtschaftswissenschaftliches Studium, Heft 1, 1984, pp. 1-7.

[6] Schneider, F., Williams, C. (2013). The Shadow Economy, Institute of Economic Affairs, Profile Books, Ltd. - Hobbs the Printers, London 2013, p. 25.

[7] Pozo, S. (1996). Exploring the Underground Economy. Studies of Illegal and Unreported Activity, W.E. Upjohn Institute for Employment Research, Kalamazoo 1996, p. 156.

[8] Balcerowicz, L. (1997). Socjalizm, kapitalizm, transformacja, Szkice $\mathrm{z}$ przełomu epok, PWN, Warszawa 1997.

[9] Rajewski, Z. Zienkowski, L. (1996). Szara gospodarka $w$ systemie rachunków narodowych, [in:] Szara gospodarka w 
Polsce. Rozmiary, przyczyny, konsekwencje, ZBSE GUS i PAN, Zeszyt 233, Warszawa 1996, p. 13.

[10] Dzierżawski, K. (2006). Krótki kurs ekonomii praktycznej, Wydawnictwo Zysk I Spółka, Warszawa 2006, p. 85.

[11] Dankiewicz., R OstrowskaDankiewicz, A., \& Bulut. C. (2020). The attitudes of entrepreneurs of the small and medium-sized enterprises sector in Poland to key business risks. Equilibrium. Quarterly Journal of Economics and Economic Policy, 15(3), p. 512, doi: 10.24136/eq.2020.023.

[12] Chłodnicka, H.; Zimon G.,(2020). Bankruptcu Risk Assessment Measures of Polish SMEs, WSEAS Transactions on Business and Economics, Volume 17, 2020, pp. 14-20.

[13] Rachunki narodowe wedtug sektorów i podsektorów instytucjonalnych $w$ latach 2015-2018, GUS, Warszawa 2020, p. 95.

[14] Rachunki narodowe wedtug sektorów i podsektorów instytucjonalnych $w$ latach 2012-2015, GUS, Warszawa 2017, p. 267.

[15] Rachunki narodowe wedlug sektorów $i$ podsektorów instytucjonalnych $w$ latach 2013-2016, GUS, Warszawa 2018, p. 281 and next.

[16] Fundowicz, J.; Łapiński, K., B. Wyżnikiewicz, D.Wyżnikiewicz, (2019). Szara strefa 2019, Instytut Prognoz i Analiz Gospodarczych, Warszawa marzec 2019, p. 24.

[17] Medina, L., Schneider, F., Shadow Economies Around the World: What Did We Learn Over the Last 20 Years?, WP/18/17, International Monetary Fund, Styczeń 2018, pp. 18, 66 and next.

[18] Medina, L., Schneider, F., Shadow Economies Around the World: What Did We Learn Over the Last 20 Years?, WP/18/17, International Monetary Fund, January 2018, p. 18, 66 i nast.

[19] Medina, L. Schneider, F., Shedding Light on the Shadow Economy: A Global Database and the Interaction with the Official One, Cesifo Working Papers No 7987, December 2019, p.30.

[20] Schneider, F., A. Buehn, (2018). Shadow Economy: Estimation Methods, Problems, Results and Open questions, Open Economics 2018, 1:1-29, p. 22; DOI 10,1515/openec-2017-0001
[21] Schneider, F., (2004). The Size of the Shadow Economies of 145 Countries all over the World, First Results over the Period 1999 to 2003, IZA, Discussion Paper No. 1431, 2004;

[22] Schneider, F. Size and Development of the Shadow Economy of 31 European and 5 other OECD Countries from 2003 to 2015, WWW. Econ.jku.at/Schneider/foles/publications, January 20, 2015

[23] Dankiewicz, R.; Szymańska, A. (2020). Bankruptcy in Polish conditions an analysis of the scale of the phenomenon over time. Journal of Security and Sustainability Issues, 10(1), p. 183 http://doi.org/10.9770/jssi.2020.10.2(15)

[24] Zimon, G., Zimon D., (2019).The Impact of Quality Management Systems on Financial Liquidity in Companies in Group Purchasing Organizations, WSEAS Transactions on Business and Economics, Volume 16, 2019, pp. 163-170.

[25] Paminto, A ., Ulfah Y., et al.,(2020). Structure of Corporate Governance Important to Reduce Manipulation of Financial Statement: The Empirical Studies in the Indonesia Context, International Journal of Advanced Science and Technology Vol. 29, No.4, pp. $5001-$ 5013.

[26] Ulfah, Y. (2020). Employees are faced with whistleblowing reporting channel alternatives: Which one is more desirable?, Revista Espacios, Vol. 41 (31), p. 18-32.

[27] Wijaya A., Dio Caisar Darma D. ., T. Pusriadi., (2020). How Contribute and the Growth of Regional Original Income? A Typology Empirical, International Journal of Academic Research in Accounting, Finance and Management Sciences 10 (2); p.140-156; DOI: 10.6007/IJARAFMS/v10-i2/7404.

[28] Aslan A., Dio Caisar Darma, A. Wijaya., (2019). Have Village Funds Impact Growth Economy And Poverty Rate?, International Journal Of Scientific \& Technology Research, vol. 8, ISSUE 10, p. 2601-2605.

[29] Torgler, B. (2007). Tax Compliance and Tax Morale. A Theoretical and Empirical Analysis, Edward Elgar Publishing Limited 2007, p.191. 
[30] Pasternak-Malicka, M. (2019). Szara strefa - definicje, przyczyny, szacunki. Polska perspektywa, Studia BAS, Biura Analiz Sejmowych Kancelarii Sejmu, Uwarunkowania prowadzenia działalności gospodarczej $w$ Polsce, $\mathrm{Nr}$ 2(58), Warszawa 2019, p. 29-56.

[31] Andrei V. Orlov, Aleksandr V. Sulimov, Sergei F. Sergeev, Anna V. Ovcharova, The Impact of Circular Economy Indicators on the Gross Inland Consumption of the Energy of the European Union, WSEAS Transactions on Environment and Development, pp. 32-45 Volume 15, 2019

[32] Atikah Nurhayati, Isah Aisyah, Asep K. Supriatna, The Relevance of Socioeconomic Dimensions in Management and Governance of Sea Ranching, WSEAS Transactions on Environment and Development, pp. 78-88, Volume 15, 2019

[33] Bolfa Traian Eugen, Studies Regarding Tourism Development Perspectives in the Existing Economical and Environmental Context, WSEAS Transactions on Environment and Development, pp. 197-203, Volume 15, 2019

\section{Contribution of individual authors to the creation of a scientific article (ghostwriting policy)}

\section{Author Contributions:}

Monika Pasternak-Malicka- responsible for organizing and conducting the study, systematizing data, reviewing the literature, developing content, analysis, statistics, systematizing data, content development.

\section{Creative Commons Attribution License 4.0 (Attribution 4.0 International, CC BY 4.0)}

This article is published under the terms of the Creative Commons Attribution License 4.0 https://creativecommons.org/licenses/by/4.0/de ed.en_US 